\title{
Serpulina alvinipulli sp. nov., a new Serpulina species that is enteropathogenic for chickens
}

\author{
T. B. Stanton, ${ }^{1}$ D. Postic ${ }^{2}$ and N. S. Jensen ${ }^{1}$ \\ Author for correspondence: T. B. Stanton. Tel: +1515239 8495. Fax: +1 5152398458. \\ e-mail: tstanton@nadc.ars.usda.gov
}

1 Enteric Diseases and Food Safety Research Unit, National Animal Disease Center, USDA, Agricultura Research Service, National Animal Disease Center, PO Box 70, Ames, IA 50010, USA

2 Unité Bactériologie Moléculaire et Médicale, Institut Pasteur, 75724 Paris cedex 15, France

\begin{abstract}
Strain $\mathrm{C1}^{\mathrm{T}}$ is an anaerobic spirochaete that causes intestinal disease in chickens. Multilocus enzyme electrophoresis analysis and 16S rRNA sequence comparisons have indicated that this spirochaete is a Serpulina strain. In these investigations, various phenotypic and genomic properties useful for establishing a taxonomic identity for strain $\mathrm{C1}^{\top}$ were studied. As determined by electron microscopy, cells of the spirochaete measured 8-11 $\times 0.22-0.34 \mu \mathrm{m}$ and had a typical spirochaete ultrastructure. Each cell had 22-30 flagella. C1' cells formed weakly $\beta$-haemolytic colonies on trypticase soy agar plates containing $5 \%$ bovine blood. The spirochaete reached maximum population densities of $10^{9}$ cells $\mathrm{m}^{-1}$ with a 2-4 $\mathrm{h}$ population doubling time in brain heart infusion broth containing $10 \%$ calf serum (BHIS broth). C1 $^{\top}$ cultures in BHIS broth were positive in tests for hippurate hydrolysis and negative for indole production. Glucosamine, $\mathbf{N}$-acetylglucosamine, glucose, fructose, maltose and mannose were growth substrates for the spirochaete in heart infusion broth containing $7 \%$ calf serum (HS broth). During growth in HS broth beneath an $\mathrm{O}_{2} / \mathrm{N}_{2}(1: 99)$ atmosphere, cells of the spirochaete consumed $\mathrm{O}_{2}$ and glucose and produced $\mathrm{H}_{2}, \mathrm{CO}_{2}$, acetate, butyrate and ethanol. Strain $\mathrm{C1}^{\top}$ DNA had a $\mathrm{G}+\mathrm{C}$ content of 24.6 mol\%. Based on DNA-DNA hybridization analyses, the DNA of strain C1' exhibited 24-39\% relative reassociation with DNA of Serpulina hyodysenteriae, Serpulina innocens, Serpulina pilosicoli, Serpulina murdochii and Serpulina intermedia. These results indicate that chicken spirochaete strain $\mathrm{C1}^{\top}$ has many phenotypic properties common to Serpulina species and, based on DNA hybridization analysis, represents a unique Serpulina species. For this new species the name Serpulina alvinipulli is proposed, for which the type strain is C1' ( = ATCC 51933').
\end{abstract}

Keywords: Serpulina alvinipulli sp. nov., enteropathogenic bacteria, spirochaetes, chickens

\section{INTRODUCTION}

Unidentified spirochaetes have been implicated as transmissible, aetiological agents of intestinal disease in commercially raised chickens. Spirochaetes at high population densities have been observed colonizing the caecal mucosae of egg-laying hens with diarrhoea (Swayne et al., 1992; Trampel et al., 1994). Spirochaetes have been detected more frequently in faecal samples from chickens with intestinal disorders than in samples from healthy birds (Dwars et al., 1989).

Abbreviation: MEE, multilocus enzyme electrophoresis.
Evidence for the enteropathogenic nature of a specific chicken spirochaete was provided by Davelaar et al. (1986), who demonstrated that the cells of a spirochaete isolated from a diarrhoeic hen both colonized the caeca and induced diarrhoea in chickens fed pure cultures of the spirochaete. The bacterium was weakly haemolytic, did not produce indole and had 26-30 periplasmic flagella per cell (13-15 inserted at each cell end). To our knowledge, this spirochaete has not been characterized further.

Swayne et al. (1995) described a weakly haemolytic spirochaete, strain $\mathrm{Cl}^{\mathrm{T}}\left(91-1207 / \mathrm{Cl}^{\mathrm{T}}\right)$, that biochemically and morphologically resembled the bacterium isolated by Davelaar et al. (1986). The spiro- 
chaete was isolated from a chicken with diarrhoea and was enteropathogenic for both 1-d-old chicks and laying hens. Strain $\mathrm{Cl}^{\mathrm{T}}$ has a similar cell ultrastructure and shares certain phenotypical traits with the swine intestinal spirochaetes Serpulina hyodysenteriae and Serpulina innocens. Nevertheless, this chicken spirochaete could be distinguished from the swine spirochaetes based on 16S rDNA restriction patterns and multilocus enzyme electrophoretic (MEE) profiles (Swayne et al., 1995). A 1416 bp region of the chicken spirochaete 16S rRNA gene had 98-99\% sequence similarity with corresponding regions of $S$. hyodysenteriae strain $\mathrm{B} 78^{\mathrm{T}}, S$. innocens strain $\mathrm{B} 256^{\mathrm{T}}$ and Serpulina pilosicoli strain $\mathrm{P} 43 / 6 / 78^{\mathrm{T}} 16 \mathrm{~S}$ rRNA genes, indicating that $\mathrm{Cl}^{\mathrm{T}}$ is properly considered as a Serpulina species (Stanton et al., 1996).

The goal of the research described in this article was to determine physiological and genomic characteristics useful for the taxonomic identification of chicken spirochaete strain $\mathrm{Cl}^{\mathrm{T}}$. The results of these studies indicate that strain $\mathrm{Cl}^{\mathrm{T}}$ represents a new Serpulina species. For this species, we propose the name Serpulina alvinipulli sp. nov. ('Serpulina of a diarrhoeic chicken') and use this species designation throughout this paper. A culture of the proposed type strain $S$. alvinipulli $\mathrm{Cl}^{\mathrm{T}}$ has been deposited with the American Type Culture Collection under the accession number ATCC $51933^{\mathrm{T}}$.

\section{METHODS}

Bacterial strain and culture conditions. S. hyodysenteriae strains B $78^{\mathrm{T}}$ and B204 were used as control strains in these studies. $S$. alvinipulli strain $\mathrm{Cl}^{\mathrm{T}}$ was originally provided by David Swayne, Ohio State University, and has been preserved in the NADC stock culture collection. Cells of these spirochaetes were cultured routinely in brain heart infusion broth containing $10 \%$ calf serum (BHIS) beneath an initial culture atmosphere of $\mathrm{O}_{2} / \mathrm{N}_{2}$ (1:99). Culture media and incubation conditions followed those used for Serpulina (Treponema) hyodysenteriae (Stanton \& Lebo, 1988). All investigations used cultures in the exponential phase of growth, that is when the culture $\mathrm{OD}_{620}$ was $0.9-1.0$ (anaerobic culture tubes, $18 \mathrm{~mm}$ path length), equivalent to $2-5 \times 10^{8}$ cells $\mathrm{ml}^{-1}$ culture (direct cell counts, PetroffHausser counting chamber). Calf serum was heat-treated $\left(56^{\circ} \mathrm{C}\right.$ for $\left.30 \mathrm{~min}\right)$ prior to addition to culture media.

DNA analysis. DNA was extracted and purified from various Serpulina species by using a modified Marmur technique (Marmur, 1961; Stanton et al., 1991). DNA relatedness was estimated by the S1 nuclease method (Crosa et al., 1973) as described previously (Grimont et al., 1980). The mol\% $\mathrm{G}+\mathrm{C}$ content of $S$. alvinipulli DNA was determined by thermal denaturation using DNA at a final concentration of $50 \mu \mathrm{g} \mathrm{ml}^{-1}$ in $0 \cdot 1 \times \mathrm{SSC}$ (Stanton et al., 1997). A Beckman DU 650 spectrophotometer equipped with a Peltier temperature-controlled cuvette holder was used to determine $T_{\mathrm{m}}$ values (Beckman Instruments). $S$. hyodysenteriae B78 DNA $(25 \pm 1 \mathrm{~mol} \%)$ was used as a control.

Phase-contrast and electron microscopy. S. alvinipulli $\mathrm{C}^{\mathrm{T}}$ cell suspensions for phase-contrast micrography were prepared and photographed as described for S. pilosicoli (Trott et al., 1996a). For electron microscopy of negatively stained bacteria, cells of strain $\mathrm{C}^{\mathrm{T}}$ were harvested from $1 \mathrm{ml}$ BHIS culture (approximately $2 \times 10^{8}$ bacteria, direct cell counts) by centrifugation (microfuge, $14000 \mathrm{~g}$ for $5 \mathrm{~min}$ ). The pelleted bacteria were washed once by suspending them in $0.5 \mathrm{ml}$ sterile distilled water and, after a second centrifugation step, the final cell pellet was resuspended in $0.1 \mathrm{ml}$ water. A sample of the cell suspension was mixed with an equal volume of $2 \%$ phosphotungstic acid $(\mathrm{pH} 7)$ and viewed by electron microscopy as described previously (Trott et al., 1996a). Twenty cells were examined to determine their dimensions and the number of flagella attached at each end of the cell.

Biochemical tests. Biochemical characteristics were determined for three different BHIS cultures of strain $\mathrm{Cl}^{\mathrm{T}}$. A standard test for hippurate hydrolysis (Smibert \& Krieg, 1981) was used with the following modifications. $S$. alvinipulli $\mathrm{Cl}^{\mathrm{T}}$ cells were harvested from $0 \cdot 1 \mathrm{ml} \mathrm{BHIS}$ culture by centrifugation in a microfuge $(16000 \mathrm{~g}$ for $10 \mathrm{~min})$, washed once in $0.5 \mathrm{ml}$ TBS (Tris-buffered saline: $0.01 \mathrm{M}$ Tris, $0.85 \% \mathrm{NaCl}, \mathrm{pH} 7 \cdot 4$ ) and resuspended in $0.02 \mathrm{ml} \mathrm{TBS}$. The final cell suspension was added to $0.4 \mathrm{ml} 1 \%$ sodium hippurate solution and incubated at $37^{\circ} \mathrm{C}$. After $30 \mathrm{~min}$, $0.2 \mathrm{ml}$ ninhydrin reagent was layered on top and the reaction mix incubated at $37^{\circ} \mathrm{C}$ for $6-8 \mathrm{~h}$. The aqueous phase became purplish-blue if cells gave a positive reaction (hydrolysed hippurate). Cultures of $S$. pilosicoli $\mathrm{P} 43 / 6 / 78^{\mathrm{T}}$ (hydrolysing hippurate) and $S$. hyodysenteriae $\mathrm{B}^{\mathrm{T}} \mathrm{P}^{\mathrm{T}}$ (non-hydrolysing hippurate) were used as controls. Indole production was assayed by the Erlich indole test (Finegold \& Martin, 1982) using $S$. alvinipulli $\mathrm{Cl}^{\mathrm{T}}$ cultures in BHIS broth $\left(3-5 \times 10^{8}\right.$ cells $\left.\mathrm{ml}^{-1}\right)$. S. hyodysenteriae B $78^{\mathrm{T}}$ and $S$. innocens $\mathrm{B} 256^{\mathrm{T}}$ cultures were used as positive and negative controls, respectively, for the indole reaction. The API AN-IDENT test system for various enzymic activities was used according to the manufacturer's instructions (bioMérieux Vitek).

Growth substrates. Methods for identifying growth substrates of $S$. alvinipulli strain $\mathrm{Cl}^{\mathrm{T}}$ followed those used for $S$. hyodysenteriae (Stanton \& Lebo, 1988). A chemical compound was considered to support growth if $S$. alvinipulli final cell densities in medium containing the compound were more than twofold greater than cell densities in medium without added substrate. Final population densities were determined by direct cell counts (Petroff-Hausser counting chamber) after cultures reached maximum optical density readings $\left(\mathrm{OD}_{620}\right)$. HS (heart infusion plus serum) broth used in these studies contained $7 \%(\mathrm{v} / \mathrm{v})$ heat-treated calf serum. For testing starch as a growth substrate, the calf serum was heat treated a second time at $65^{\circ} \mathrm{C}$ for $30 \mathrm{~min}$ to inactivate endogenous starch-hydrolysing activity.

Analysis of metabolic substrates and products. Metabolic products were determined for $S$. alvinipulli cells growing in $7 \mathrm{ml}$ HS broth (heart infusion broth, $10 \%$ serum, $0.2 \%$ glucose) beneath an initial $\mathrm{O}_{2} / \mathrm{N}_{2}(1: 99$, by vol.) atmosphere. Calf serum used in the media for metabolic studies was heat treated as described above and was additionally heated at $65^{\circ} \mathrm{C}$ for $30 \mathrm{~min}$ to inactivate endogenous, $\mathrm{O}_{2}$-scavenging activities that interfered with assays of $\mathrm{O}_{2}$ consumption by bacterial cultures. Methods and equipment for analysing volatile fatty acids and alcohols by GLC have been reported previously (Stanton \& Lebo, 1988; Trott et al., 1996a). Gases produced $\left(\mathrm{H}_{2}\right.$ and $\left.\mathrm{CO}_{2}\right)$ and consumed $\left(\mathrm{O}_{2}\right)$ by the bacteria were identified and quantified by GC using samples of the culture atmosphere as described previously (Trott et al., 1996a), except that argon was used as a carrier gas to 
detect $\mathrm{H}_{2}$. To avoid introducing air $\left(\mathrm{O}_{2}\right)$, samples of culture atmospheres were taken through the stoppers of culture tubes placed within a Coy anaerobic chamber and by positive displacement (after injecting an equal volume of $\mathrm{O}_{2}$-free water into the culture tube). Uninoculated culture tubes containing sterile media were incubated and used as controls for all assays.

RFLP-PCR analysis of 165 rDNA. A portion (approximately $558 \mathrm{bp}$ ) of the rrs gene of $S$. alvinipulli was amplified and analysed for restriction fragment length polymorphisms (RFLPs; Stanton et al., 1997). The PCR amplification (forward primer, 5'-GGAAACGCCTCGGATACTGT-3'; reverse primer, 5'-CCTTCCTCCTACTTGAACGTA-3') was specific for Serpulina species and Brachyspira aalborgi (Stanton et al., 1997). The restriction enzymes Sau3A, TaqI, HinfI, MboII and SphI were used according to the manufacturer's directions. Restriction fragments were separated by electrophoresis $(65 \mathrm{~V}$ for $2 \mathrm{~h}$ ) on a $4 \%$ NuSieve $(3: 1)$ gel (FMC Bioproducts) in $1 \times$ TAE buffer and visualized by ethidium bromide staining (Sambrook et al., 1989; Stanton et al., 1997). Fragment sizes were estimated by comparison with DNA fragments of known size (size range 36-2645 bp; D-15 DNA marker, Novex Technology).

\section{RESULTS}

\section{DNA relatedness and $\mathbf{G}+\mathrm{C}$ content}

The estimated DNA relatedness between $S$. alvinipulli $\mathrm{C1}^{\mathrm{T}}$ DNA and the DNA of other Serpulina species ranged between 24 and $39 \%$ (Table 1), indicating that $\mathrm{Cl}^{\mathrm{T}}$ is a distinct Serpulina species. In two determinations using the thermal denaturation method, the $\mathrm{G}+\mathrm{C}$ content of $S$. alvinipulli $\mathrm{Cl}^{\mathrm{T}}$ DNA was $24.6 \mathrm{~mol} \%$. In parallel determinations, $S$. hyodysenteriae $\mathrm{B} 78^{\mathrm{T}}$ DNA and E. coli XL-1 DNA had 24.2 and $50.8 \mathrm{~mol} \% \mathrm{G}+\mathrm{C}$, respectively.

\section{Cell morphology}

By phase-contrast microscopy (Fig. 1), S. alvinipulli $\mathrm{Cl}^{\mathrm{T}}$ cells had a mean length of $9.5 \mu \mathrm{m}$, slightly larger than Serpulina hyodysenteriae $\mathrm{B} 78^{\mathrm{T}}$ cells (mean cell
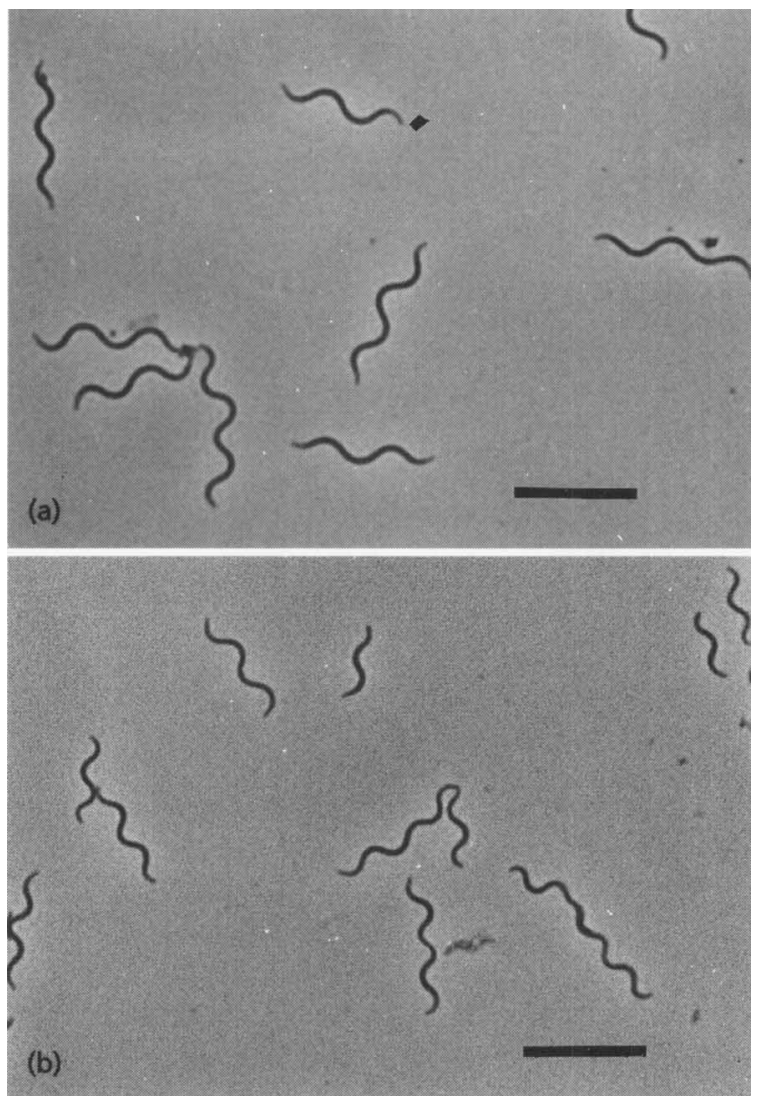

Fig. 1. (a) S. alvinipulli $\mathrm{Cl}^{\top}$ cells. (b) S. hyodysenteriae B78 ${ }^{\top}$ cells. Phase-contrast photomicrographs of wet-mount preparations. Bars, $10 \mu \mathrm{m}$.

length $7 \mu \mathrm{m}$ ). When examined by electron microscopy (Fig. 2), $\mathrm{Cl}^{\mathrm{T}}$ cells had a typical spirochaete ultrastructure with equal numbers of flagella attached near each end of the cells. Cells of the spirochaete had an outer sheath, helical protoplasmic cylinder and peri-

\section{Table 1. DNA-DNA relative reassociation between various Serpulina species}

Relative reassociation values for $\mathrm{Cl}^{\mathrm{T}}$ were determined in this study. Values for other Serpulina species were reported previously (Stanton et al., 1997). Values in parentheses are $\Delta T_{\mathrm{m}}$.

\begin{tabular}{|c|c|c|c|c|c|c|}
\hline \multirow{2}{*}{$\begin{array}{l}\text { Source of unlabelled } \\
\text { DNA }\end{array}$} & \multicolumn{6}{|c|}{ Source of labelled DNA } \\
\hline & ${\text { B } 78^{\mathrm{T}}}^{\mathrm{T}}$ & B256 $^{\mathrm{T}}$ & WES-B & $\mathbf{P W S} / \mathbf{A}^{\mathrm{T}}$ & $56-150^{\mathrm{T}}$ & $\mathrm{C} 1^{\mathrm{T}}$ \\
\hline S. hyodysenteriae $\mathrm{B} 78^{\mathrm{T}}$ & 100 & & 25 & $57(7)$ & 27 & 33 \\
\hline S. innocens $\mathrm{B} 256^{\mathrm{T}}$ & 29 & 100 & 22 & $45(12)$ & $66(7)$ & 32 \\
\hline S. pilosicoli $\mathrm{P} 43 / 6 / 78^{\mathrm{T}}$ & 21 & 23 & 78 & 28 & 22 & \\
\hline S. pilosicoli WES-B & 28 & 29 & 100 & 26 & 28 & 24 \\
\hline S. intermedia $\mathrm{PWS} / \mathrm{A}^{\mathrm{T}}$ & $68(8)$ & 44 & 30 & 100 & 24 & 39 \\
\hline S. murdochii $56-150^{\mathrm{T}}$ & 37 & $64(5)$ & & $37(15)$ & 100 & 35 \\
\hline S. alvinipulli $\mathrm{Cl}^{\mathrm{T}}$ & 28 & 37 & 28 & 37 & 31 & 100 \\
\hline
\end{tabular}




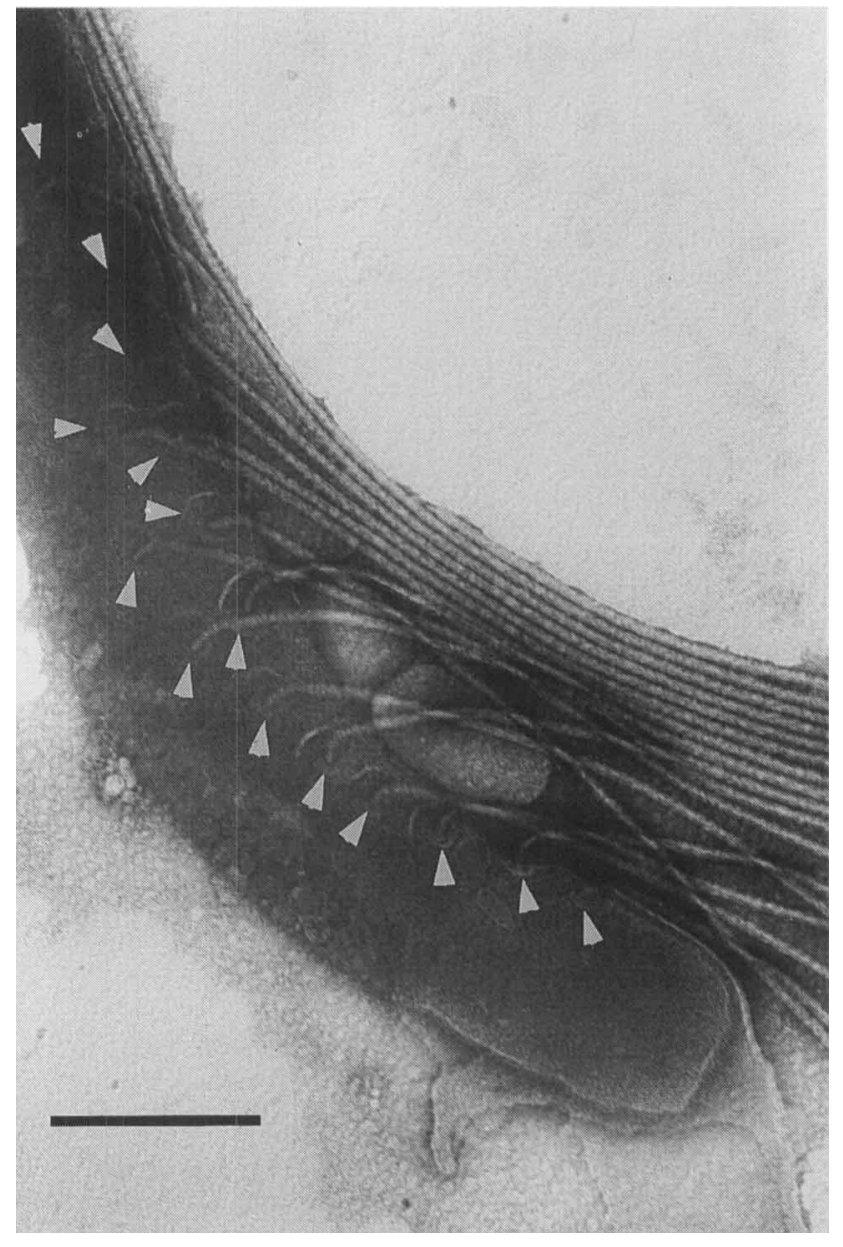

Fig. 2. Electron micrograph of $S$. alvinipulli $C 1^{\top}$ cell negatively stained with PTA ( $2 \%, \mathrm{pH} 7.0)$. Disrupted outer sheath enables insertion sites of 15 periplasmic flagella to be seen (white arrowheads). Bar, $0.25 \mu \mathrm{m}$.

plasmic flagella that appeared to wrap around the protoplasmic cylinder and overlapped in the centre of the cell. The cells measured 8-11 ×0.22-0.34 $\mu \mathrm{m}$ and had 22-30 (mean $=24)$ flagella per cell with 11-15 attached at each end (Fig. 2). Similar flagellar numbers have been reported for $S$. hyodysenteriae cells (Stanton et al., 1997). Previously, strain $\mathrm{Cl}^{\mathrm{T}}$ and $S$. hyodysenteriae $\mathrm{B} 78^{\mathrm{T}}$ cells were reported to have 16 flagella per cell (Swayne et al., 1995). However, in those studies, cross-sections of the spirochaetes were examined by electron microscopy. We believe that more accurate estimates of flagellar numbers can be obtained using negatively stained bacteria and counting both flagella and flagellar attachment sites.

\section{Culture characteristics}

S. alvinipulli $\mathrm{Cl}^{\mathrm{T}}$ cultures were positive for hippurate hydrolysis. Control cultures of $S$. hyodysenteriae $\mathrm{B} 78^{\mathrm{T}}$ and $S$. pilosicoli $\mathrm{P} 43 / 6 / 78^{\mathrm{T}}$ were negative and positive

\section{Table 2. Growth substrates of S. alvinipulli $\mathrm{C} 1^{\top}$}

The following compounds did not support detectable growth of $S$. alvinipulli $\mathrm{C1}^{\mathrm{T}}$ : sucrose, D-galactose, D-trehalose, pyruvate, lactose, L-rhamnose, D-melibiose, D-fucose, Lfucose, D-raffinose, L-arabinose, D-ribose, D-xylose, $N$-acetylD-galactosamine, D-galactosamine, D-mannitol, glycerol, acetate, lactate, succinate, pebble-milled cellulose, pectin, soluble starch, hog gastric mucin, glycogen, hyaluronic acid, polygalacturonic acid, $50 \times \mathrm{MEM}$ amino acids glutathione.

\begin{tabular}{|lcc|}
\hline Substrate & $\begin{array}{r}\text { Incubation } \\
\text { period (h) }\end{array}$ & $\begin{array}{c}\text { Max. } \\
\text { population } \\
\text { density } \\
\left(\mathbf{1 0}^{-\mathbf{8}} \times \mathbf{)}\right.\end{array}$ \\
\hline None & $36-48$ & $1 \cdot 3$ \\
D-Glucose & $24-36$ & $8 \cdot 0$ \\
D-Mannose & $36-48$ & $10 \cdot 0$ \\
D-Maltose & $24-36$ & $8 \cdot 0$ \\
D-Glucosamine & $36-48$ & $9 \cdot 5$ \\
$N$-Acetyl-D-glucosamine & $36-48$ & $9 \cdot 5$ \\
D-Fructose & $36-48$ & $3 \cdot 4$ \\
\hline
\end{tabular}

for hippurate hydrolysis, respectively, as reported previously (Trott et al., 1996a). $\mathrm{Cl}^{\mathrm{T}}$ cultures did not produce detectable amounts of indole. $S$. hyodysenteriae $\mathrm{B} 78^{\mathrm{T}}$ gave a positive indole reaction, and $S$. innocens $\mathrm{B} 256^{\mathrm{T}}$ gave a negative reaction. The population doubling time of $\mathrm{Cl}^{\mathrm{T}}$ cells in BHIS broth at $37^{\circ} \mathrm{C}$ was $2-4 \mathrm{~h}$. Cells of the spirochaete grew more rapidly in BHIS broth at either $39^{\circ} \mathrm{C}$ or $42^{\circ} \mathrm{C}$ than at $37^{\circ} \mathrm{C}$ and did not grow at 32 or $47^{\circ} \mathrm{C}$. Initial culture atmospheres containing $5 \%(\mathrm{v} / \mathrm{v})$ or less $\mathrm{O}_{2}$ did not prevent growth of $\mathrm{Cl}^{\mathrm{T}}$. The minimum calf serum concentration supporting optimum growth (highest cell yields in shortest incubation times) in HS broth was $7 \%$, and this concentration was used in HS broth to determine growth substrates. S. alvinipulli $\mathrm{Cl}^{\mathrm{T}}$ cells used a limited number of tested carbohydrates as growth substrates (Table 2).

The results of the API AN-IDENT test kit for determining the biochemical properties of strain $\mathrm{Cl}^{\mathrm{T}}$ cultured in BHIS broth are given below in the species description. Results of tests with $S$. hyodysenteriae B204 agreed with those reported previously for strains of this species (Hunter \& Wood, 1979; Fellström, 1995; Fellström et al., 1995). Enzymic activities for $S$. alvinipulli $\mathrm{Cl}^{\mathrm{T}}$ cells were consistent with those reported previously for this strain, except for $\alpha$-galactosidase (Swayne et al., 1995). Variations in culture conditions may explain this difference.

Interestingly, the biochemical reactivities determined in the AN-IDENT colorimetric tests were not always consistent with growth substrate results of the spirochaete. S. alvinipulli $\mathrm{Cl}^{\mathrm{T}}$ gave a positive reaction for $\beta$ galactosidase yet was unable to use lactose for growth (Table 2). S. alvinipulli cells were negative in tests for $\alpha$ - 
Table 3. Metabolic end products of growing cells of S. alvinipulli $\mathrm{C}^{\top}$

For end product determinations, $S$. alvinipulli and $S$. hyodysenteriae cells were cultured beneath a $1 \% \mathrm{O}_{2}$ atmosphere (balance $\mathrm{N}_{2}$ ) in HS broth containing $10 \%$ calf serum and $0.2 \%$ glucose. During growth, cells of both species consumed $\mathrm{O}_{2}$ in the culture atmosphere [estimated to be 1-1.2 $\mu \mathrm{mol} \mathrm{O}_{2}(\mathrm{ml} \text { culture broth })^{-1}$.

\begin{tabular}{|lcc|}
\hline Product & \multicolumn{2}{c|}{ Yield ( $\mu \mathrm{mol} \mathrm{ml}^{-1}$ medium) with: } \\
\cline { 2 - 3 } & $\begin{array}{c}\text { S. alvinipulli } \\
\text { C1 }^{\mathrm{T}}\end{array}$ & $\begin{array}{c}\text { S. hyodysenteriae } \\
\text { B204 }\end{array}$ \\
\hline Acetate & $16 \cdot 8$ & $11 \cdot 8$ \\
Butyrate & $0 \cdot 8$ & $2 \cdot 9$ \\
Ethanol & $2 \cdot 2$ & TR \\
$\mathrm{CO}_{2}$ & $19 \cdot 4$ & $22 \cdot 8$ \\
$\mathrm{H}_{2}$ & $22 \cdot 8$ & $32 \cdot 0$ \\
\hline
\end{tabular}

$\mathrm{TR}, \operatorname{trace}\left[\leqslant 0 \cdot 2 \mu \mathrm{mol}(\mathrm{ml} \text { medium })^{-1}\right]$.

glucosidase, yet this spirochaete used maltose as a growth substrate (Table 2), suggesting the possible existence of an inducible mechanism for maltose metabolism.

\section{Metabolic products}

S. alvinipulli $\mathrm{Cl}^{\mathrm{T}}$ cells growing in $\mathrm{HS}$ broth beneath an atmosphere containing $\mathrm{O}_{2} / \mathrm{N}_{2}(1: 99)$ consumed oxygen and glucose and produced $\mathrm{H}_{2}, \mathrm{CO}_{2}$, acetate, butyrate and ethanol (Table 3). Unlike $S$. hyodysenteriae, $S$. alvinipulli cells produced significant amounts $\left[2 \cdot 2 \mu \mathrm{mol}\left(\mathrm{ml}\right.\right.$ culture broth) $\left.{ }^{-1}\right]$ of ethanol, and the ratio of $\mathrm{H}_{2}$ to $\mathrm{CO}_{2}$ produced by $S$. alvinipulli was closer to 1 (Table 3).

\section{RFLP-PCR test}

Based on RFLP-PCR analysis of an amplified product of the 16S rRNA gene, $S$. alvinipulli $\mathrm{Cl}^{\mathrm{T}}$ could be differentiated from $S$. innocens $\mathrm{B} 256^{\mathrm{T}}$ (HinfI digests) $S$. pilosicoli $\mathrm{P} 43 / 6 / 78^{\mathrm{T}}$ (TaqI digest), S. murdochii 56-150 ${ }^{\mathrm{T}}$ (Sau3A and HinfI digests) and from the human intestinal spirochaete $B$. aalborgi (MboII digest) (Table 4). The chicken spirochaete could not be differentiated from $S$. hyodysenteriae $\mathrm{B} 78^{\mathrm{T}}$ or $S$. intermedia PWSA $^{\mathrm{T}}$ using these restriction enzymes. Analyses of the predicted sequences of the 16S rDNA amplicons of B. aalborgii $513 \mathrm{~A}^{\mathrm{T}}$ and of the Serpulina species for sites of 420 restriction enzymes did not reveal any site unique to the $\mathrm{C1}^{\mathbf{T}}$ sequence (Heiman, 1997).

\section{DISCUSSION}

Based on 16S rDNA sequence comparisons, MEE analysis in previous studies (Swayne et al., 1995; Stanton et al., 1996) and phenotypical characteristics determined in these studies, avian intestinal spirochaete strain $\mathrm{Cl}^{\mathrm{T}}$ is phylogenetically related to Serpulina species and should be considered as a Serpulina species. The DNA relatedness between strain $\mathrm{Cl}^{\mathrm{T}}$ and other Serpulina species was estimated to be 24-39\% (Table 1). As these values are below the cutoff value of $70 \%$ DNA relatedness that has been recommended for phylogenetic definition of a species (Wayne et al., 1987), strain $\mathrm{Cl}^{\mathrm{T}}$ is properly considered as a new species of Serpulina. We propose the designation Serpulina alvinipulli (Serpulina of a diarrhoeic chicken) for this new species and

Table 4. Restriction enzyme digestion of 165 rDNA amplicons of Serpulina species and B. aalborgi $513 \mathrm{~A}^{\top}$

A portion of the rrs gene was amplified from chromosomal DNA of each strain by PCR and digested using the indicated restriction enzyme (Stanton et al., 1997). Values in the table represent fragment sizes (bp) either observed directly after gel electrophoresis ( $>75 \mathrm{bp}$ ) of the restriction digests or predicted ( $<75 \mathrm{bp}$ ) based on the 16S rDNA sequences of the strains when the PCR amplification product was cut with a particular restriction enzyme. Fragments below $75 \mathrm{bp}$ could not be detected after gel electrophoresis.

\begin{tabular}{|lcccc|}
\hline 16S rDNA amplicon from & \multicolumn{4}{c|}{ Restriction fragments (bp) } \\
\cline { 2 - 5 } & HinfI & Sau3A & TaqI & MboII \\
\hline S. hyodysenteriae B78 & & & & \\
S. innocens B256 & 132,426 & 558 & $43,81,208,226$ & 558 \\
S. pilosicoli P43/6/78 & $21,111,426$ & 558 & $43,81,208,226$ & 558 \\
S. intermedia PWS/A & 132,426 & 558 & $43,43,183,208$ & 558 \\
S. murdochii $56-150^{\mathrm{T}}$ & 132,426 & 558 & $43,81,208,226$ & 558 \\
S. alvinipulli $\mathrm{C1}^{\mathrm{T}}$ & $21,111,426$ & 187,371 & $43,81,208,226$ & 558 \\
B. aalborgi $513 \mathrm{~A}^{\mathrm{T}}$ & 132,426 & 558 & $43,81,208,226$ & 558 \\
& 132,422 & 558 & $43,81,208,226$ & 85,473 \\
\hline
\end{tabular}


Table 5. Culture and biochemical characteristics of various Serpulina species and Brachyspira aalborgi $513 \mathrm{~A}^{\top}$

Spirochaete characteristics in the table are based on analyses of $S$. alvinipulli $\mathrm{C}^{\mathrm{T}}$ in these studies and on results from previous studies of the other species (Hunter \& Wood, 1979; Hovind-Hougen et al., 1982; Fellström, 1995; Fellström et al., 1995, 1997; McLaren et al., 1997; Stanton et al., 1997). $\alpha$-gal, $\alpha$-glu and $\beta$-glu: $\alpha$-galactosidase, $\alpha$-glucosidase and $\beta$-glucosidase, respectively. $+/-$ indicates that some strains possess and other strains lack a particular enzyme activity. A unique 'signature' sequence of nucleotides was identified within the 16S rDNA of $S$. pilosicoli and has been used to design specific PCR tests for that spirochaete (Park et al., 1996; Fellström et al., 1997).

\begin{tabular}{|c|c|c|c|c|c|c|c|c|c|}
\hline \multirow[t]{2}{*}{ Species } & \multirow[t]{2}{*}{ Haemolysis } & \multirow{2}{*}{$\begin{array}{c}\text { Indole } \\
\text { production }\end{array}$} & \multirow{2}{*}{$\begin{array}{l}\text { Hippurate } \\
\text { hydrolysis }\end{array}$} & \multirow{2}{*}{$\begin{array}{c}\text { Demonstrated } \\
\text { pathogenicity } \\
\text { (animal) }\end{array}$} & \multirow{2}{*}{$\begin{array}{r}\text { Flagella } \\
\text { per cell }\end{array}$} & \multicolumn{3}{|c|}{ Enzyme activity: } & \multirow{2}{*}{$\begin{array}{c}\text { 16S rDNA } \\
\text { signature } \\
\text { sequence }\end{array}$} \\
\hline & & & & & & $\alpha$-Gal & $\alpha$-Glu & $\beta$-Glu & \\
\hline S. hyodysenteriae & Strong & + & - & Yes (swine) & $22-28$ & - & $+1-$ & + & No \\
\hline S. innocens & Weak & - & - & No & $20-26$ & - & $+1-$ & + & No \\
\hline S. intermedia & Weak & + & - & No & $24-28$ & - & + & + & No \\
\hline S. pilosicoli & Weak & - & + & $\begin{array}{c}\text { Yes (swine; } \\
\text { 1-d-old chicken) }\end{array}$ & $8-12$ & $+1-$ & $+1-$ & - & Yes \\
\hline S. murdochii & Weak & - & - & No & $22-26$ & - & - & + & No \\
\hline S. alvinipulli & Weak & - & + & Yes (chickens) & $22-30$ & - & - & + & No \\
\hline B. aalborgi & Weak & $?$ & $?$ & No & 8 & - & - & - & No \\
\hline
\end{tabular}

recommend that strain $\mathrm{Cl}^{\mathrm{T}}$ be considered the type strain.

S. alvinipulli $\mathrm{Cl}^{\mathrm{T}}$ cells have a number of biochemical properties in common with other Serpulina species. $S$. alvinipulli is a carbohydrate-fermenting, anaerobic spirochaete that produces ethanol, acetate, butyrate, $\mathrm{H}_{2}$ and $\mathrm{CO}_{2}$ from glucose metabolism. Under a $\mathrm{N}_{2} / \mathrm{CO}_{2}(99: 1)$ atmosphere, growing cells consume oxygen, a reaction probably mediated by NADH oxidase, as the nox gene has been detected in $S$. alvinipulli $\mathrm{Cl}^{\mathrm{T}}$ cells (Stanton et al., 1995). Both $S$. alvinipulli and $S$. hyodysenteriae produce more $\mathrm{H}_{2}$ than $\mathrm{CO}_{2}$, although the ratio of $\mathrm{H}_{2} / \mathrm{CO}_{2}$ is lower for $S$. alvinipulli than for $S$. hyodysenteriae (Table 3 ) and for other Serpulina species (Trott et al., 1996a; Stanton et al., 1997).

S. alvinipulli is the first novel Serpulina species from chickens to be isolated and characterized. Recent studies have indicated that chickens are also hosts for $S$. innocens and $S$. pilosicoli, for the newly described species $S$. intermedia and $S$. murdochii and for intestinal spirochaetes in an MEE group (group d) that is likely to represent a new Serpulina species (Trott $e t$ al., 1996b; McLaren et al., 1997; Swayne \& McLaren, 1997).

S. alvinipulli cultures have been demonstrated to cause intestinal disease when inoculated into chickens (Swayne et al., 1995). S. pilosicoli and S. intermedia strains have been implicated as intestinal pathogens of chickens (Swayne \& McLaren, 1997). Cells of $S$. alvinipulli, $S$. intermedia, $S$. pilosicoli, $S$. innocens and $S$. murdochii form weakly haemolytic colonies on trypticase soy/blood agar medium. For both taxonomic and clinical diagnostic purposes, there is a growing need for simple, reliable tests to differentiate these weakly haemolytic Serpulina species.
An RFLP-PCR test based on an amplified portion of the $r r s$ gene has been used to differentiate porcine Serpulina species (Stanton et al., 1997). In the present studies, $S$. alvinipulli $\mathrm{C}^{\mathrm{T}}$ could not be distinguished from $S$. intermedia $\mathrm{PWS} / \mathrm{A}^{\mathrm{T}}$ or $S$. hyodysenteriae $\mathrm{B} 78^{\mathrm{T}}$ by this test when the restriction enzymes HinfI, Sau3A, $T a q \mathrm{I}$ or $M b o$ II were used. These results indicate that the RFLP-PCR procedure cannot be used by itself. The test may be useful in conjunction with other tests for differentiating Serpulina species.

Fellström et al. (1997) have proposed a method for organizing porcine intestinal spirochaetes into groups based on type of haemolysis, indole reaction, hippurate hydrolysis and whether or not the spirochaete is pathogenic. These groups roughly correspond to strains of $S$. hyodysenteriae (group I), S. intermedia (group II), S. innocens (group IIIb and c), S. murdochii (group IIIa) and S. pilosicoli (group IV) (Stanton et al., 1997). Unfortunately, $S$. alvinipulli $\mathrm{Cl}^{\mathrm{T}}$ is indistinguishable from $S$. pilosicoli based on these four properties (Table 5), and both species have been isolated from chickens. Nevertheless, $S$. alvinipulli $\mathrm{Cl}^{\mathrm{T}}$ can be distinguished from S. pilosicoli on the basis of flagellar numbers per cell and a 'signature sequence' in the 16S rDNA of $S$. pilosicoli (Table 5). Culture and phenotypical characteristics useful for differentiating $S$. alvinipulli $\mathrm{C1}^{\mathrm{T}}$ from the other Serpulina species are given in Table 5 .

Knowledge of the epidemiology, incidence, economic impact and virulence aspects of intestinal spirochaete diseases is improving as pathogenic species are identified and methods for differentiating pathogenic and non-pathogenic spirochaetes are developed (Dwars $e t$ al., 1989; Swayne \& McLaren, 1997; van der Zeijst et al., 1997). Methods for differentiating Serpulina species and, especially, for identifying weakly haemolytic, 
enteropathogenic spirochaetes will undoubtedly evolve as additional, diverse strains of each Serpulina species are isolated and characterized.

\section{Description of Serpulina alvinipulli sp. nov.}

Serpulina alvinipulli (al.vi.ni.púl.li. combination of $\mathrm{L}$. gen. adj. alvini suffering from diarrhoea and L. gen. n. pulli of a chicken; alvinipulli of a diarrhoeic chicken, referring to the host animal from which the spirochaete was isolated.

Pathogenic. When inoculated by crop gavage, $S$. alvinipulli cells colonize the caeca of 1-d-old chicks and 14-month-old hens and induce mild lymphocytic typhlitis and diarrhoea. Cells grow by forming weakly haemolytic colonies on trypticase soy agar medium containing $5 \%$ defibrinated bovine blood. S. alvinipulli $\mathrm{C} 1$ cells have a typical spirochaete ultrastructure, i.e. an outer sheath, helical protoplasmic cylinder and periplasmic flagella wrapped around the protoplasmic cylinder and inside the outer sheath. The cells measure $8-11 \times 0.22-0.34 \mu \mathrm{m}$ and have 22-30 (mean 24) flagella per cell (11-15 inserted at each cell end, with free ends overlapping in the middle of the cell). Growing cells beneath an atmosphere containing $\mathrm{O}_{2} / \mathrm{N}_{2}(1: 99)$ consume oxygen. Cells possess the gene for NADH oxidase. Grows well $\left(3-10 \times 10^{8}\right.$ cells $\mathrm{ml}^{-1}$, final population densities) in HS broth containing D-glucose, Dfructose, D-mannose, D-maltose, D-glucosamine or $N$ acetyl-D-glucosamine as growth substrates. Growth not detectable with these potential substrates: sucrose, D-galactose, D-trehalose, pyruvate, lactose, L-rhamnose, D-melibiose, D-fucose, L-fucose, D-raffinose, Larabinose, D-xylose, D-ribose, D-galactosamine, $\mathrm{N}$ acetyl-D-galactosamine, D-mannitol, glycerol, acetate, lactate, succinate, pebble-milled cellulose, soluble starch, pectin, hog gastric mucin, glycogen, hyaluronic acid, polygalacturonic acid, $50 \times$ MEM amino acids or glutathione. S. alvinipulli $\mathrm{Cl}^{\mathrm{T}}$ cells cultured in BHIS (brain heart infusion supplemented with $10 \%$ heattreated calf serum) broth give positive reactions in tests for hippurate hydrolysis, $\beta$-glucosidase, $\beta$-galactosidase, alkaline phosphatase, indoxyl acetate hydrolysis, arginine aminopeptidase, alanine aminopeptidase and glycine aminopeptidase; and negative reactions in tests for indole production, $\alpha$-glucosidase, $\alpha$-galactosidase, $N$-acetyl-glucosaminidase, $\alpha$-arabinosidase, $\alpha$ fucosidase, arginine metabolism, leucine aminopeptidase, proline aminopeptidase, pyroglutamic acid arylamidase, tyrosine aminopeptidase, histidine aminopeptidase, phenylalanine aminopeptidase and catalase. Gram-negative, catalase-negative, aerotolerant anaerobe. Optimum growth temperature, $39-42{ }^{\circ} \mathrm{C}$. No growth at 32 or $47^{\circ} \mathrm{C}$. $\mathrm{G}+\mathrm{C}$ content of the DNA is $24.6 \mathrm{~mol} \%\left(T_{\mathrm{m}}\right)$. Population doubling time in BHIS is $2-4 \mathrm{~h}$. Requires serum for growth in BHIS broth. Shares high 16S rRNA sequence identity $(98-99 \%)$ with other Serpulina species ( $S$. hyodysenteriae, $S$. innocens, $S$. pilosicoli, $S$. intermedia and $S$. murdochii). Shares $24-39 \%$ DNA relatedness with the other Serpulina species based on DNA-DNA relative reassociation studies. Type strain: $\mathrm{Cl}^{\mathrm{T}}(91-$ $\left.1207 / \mathrm{Cl}^{\mathrm{T}}\right)\left(=\mathrm{ATCC} 51933^{\mathrm{T}}\right)$.

\section{NOTE ADDED IN PROOF}

Ochiai et al. recently proposed the re-designation of Serpulina species as Brachyspira species (Microbiol Immunol 41, 445-452) and published new name combinations in Validation List no. 64 (Int J Syst Bacteriol $\mathbf{4 8}, 327)$. In accordance with the rules of taxonomy, the bacterium characterized in this paper should be designated Brachyspira alvinipulli sp. nov.

\section{ACKNOWLEDGEMENTS}

The advice of Professor Hans G. Trüper regarding the nomenclature of Serpulina alvinipulli is gratefully acknowledged. The technical assistance of Sam Humphrey is greatly appreciated.

\section{REFERENCES}

Crosa, J. H., Brenner, D. J. \& Falkow, S. (1973). Use of a singlestrand specific nuclease for analysis of bacterial and plasmid deoxyribonucleic acid homo- and heteroduplexes. $J$ Bacteriol 115, 904-911.

Davelaar, F. G., Smit, H. F., Hovind-Hougen, K., Dwars, R. M. \& van der Valk, P. C. (1986). Infectious typhlitis in chickens caused by spirochetes. Avian Pathol 15, 247-258.

Dwars, R. M., Smit, H. F., Davelaar, F. G. \& Van't Veer, W. (1989). Incidence of spirochaetal infections in cases of intestinal disorder in chickens. Avian Pathol 18, 591-595.

Fellström, C. (1995). Phenotypical characterisation of intestinal spirochaetes isolated from pigs. Res Vet Sci 59, 1-4.

Fellström, C., Pettersson, B., Uhlen, M., Gunnarsson, A. \& Johansson, K.-E. (1995). Phylogeny of Serpulina based on sequence analyses of the 16S rRNA gene and comparison with a scheme involving biochemical classification. Res Vet Sci 59, 5-9.

Fellström, C., Pettersson, B., Thomson, J., Gunnarsson, A., Persson, M. \& Johansson, K.-E. (1997). Identification of Serpulina species associated with porcine colitis by biochemical analysis and PCR. $J$ Clin Microbiol 35, 462-467.

Finegold, S. M. \& Martin, W. J. (1982). Bailey and Scott's Diagnostic Microbiology, p. 668. St Louis, Toronto \& London: The C. V. Mosby Company.

Grimont, P. A. D., Popoff, M. Y., Grimont, F., Coynault, C. \& Lemelin, M. (1980). Reproducibility and correlation study of three deoxyribonucleic acid hybridization procedures. Curr Microbiol 4, 325-330.

Heiman, M. G. (1997). Webcutter, version 2, alpha release (http://www.firstmarket.com/cutter).

Hovind-Hougen, K., Birch-Andersen, A., Henrik-Nielsen, R., Orholm, M., Pedersen, J. O., Teglbjærg, P. S. \& Thaysen, E. H. (1982). Intestinal spirochetosis: morphological characterization and cultivation of the spirochete Brachyspira aalborgi gen. nov., sp. nov. J Clin Microbiol 16, 1127-1136.

Hunter, D. \& Wood, T. (1979). An evaluation of the API ZYM system as a means of classifying spirochaetes associated with swine dysentery. Vet Rec 104, 383-384. 
McLaren, A. J., Trott, D. J., Swayne, D. E., Oxberry, S. L. \& Hampson, D. J. (1997). Genetic and phenotypic characterization of intestinal spirochetes colonizing chickens, and allocation of known pathogenic isolates to three distinct genetic groups. $J$ Clin Microbiol 35, 412-417.

Marmur, J. (1961). A procedure for the isolation of deoxyribonucleic acid from microorganisms. $J \mathrm{Mol}$ Biol 3, 208-218.

Park, N. Y., Chung, C. Y., McLaren, A. J., Atyeo, R. F. \& Hampson, D. J. (1996). Polymerase chain reaction for identification of human and porcine spirochaetes recovered from cases of intestinal spirochaetosis. FEMS Microbiol Lett 125, 225-229.

Sambrook, J., Fritsch, E. F. \& Maniatis, T. (1989). Molecular Cloning: a Laboratory Manual, 2nd edn. Cold Spring Harbor, NY: Cold Spring Harbor Laboratory.

Smibert, R. M. \& Krieg, N. R. (1981). General characterization. In Manual of Methods for General Bacteriology, pp. 409-443. Washington, DC: American Society for Microbiology.

Stanton, T. B. \& Lebo, D. F. (1988). Treponema hyodysenteriae growth under various culture conditions. Vet Microbiol 18, 177-190.

Stanton, T. B., Jensen, N. S., Casey, T. A., Tordoff, L. A., Dewhirst, F. E. \& Paster, B. J. (1991). Reclassification of Treponema hyodysenteriae and Treponema innocens in a new genus, Serpula gen. nov., as Serpula hyodysenteriae comb. nov. and Serpula innocens comb. nov. Int $J$ Syst Bacteriol 41, 50-58.

Stanton, T. B., Hanzelka, B. L. \& Jensen, N. S. (1995). Survey of intestinal spirochaetes for NADH oxidase by gene probe and by enzyme assay. Microb Ecol Health Dis 8, 93-100.

Stanton, T. B., Trott, D. J., Lee, J. I., McLaren, A. J., Hampson, D. J., Paster, B. J. \& Jensen, N. S. (1996). Differentiation of intestinal spirochaetes by multilocus enzyme electrophoresis analysis and 16S rRNA sequence comparisons. FEMS Microbiol Lett 136, 181-186.

Stanton, T. B., Fournié-Amazouz, E., Postic, D., Trott, D. J., Grimont, P. A. D., Baranton, G., Hampson, D. J. \& Saint Girons, I.
(1997). Recognition of two new species of intestinal spirochetes: Serpulina intermedia $\mathrm{sp}$. nov. and Serpulina murdochii sp. nov. Int J Syst Bacteriol 47, 1007-1012.

Swayne, D. E. \& McLaren, A. J. (1997). Avian intestinal spirochaetes and avian intestinal spirochaetosis. In Intestinal Spirochaetes in Domestic Animals and Humans, pp. 267-300. Edited by D. J. Hampson \& T. B. Stanton. Wallingford \& New York: CAB International.

Swayne, D. E., Bermudez, A. J., Sagartz, J. E., Eaton, K. A., Monfort, J. D., Stoutenburg, J. W. \& Hayes, J. R. (1992). Association of cecal spirochetes with pasty vents and dirty eggshells in layers. Avian Dis 36, 776-781.

Swayne, D. E., Eaton, K. A., Stoutenburg, J., Trott, D. J., Hampson, D. J. \& Jensen, N. S. (1995). Identification of a new intestinal spirochete with pathogenicity for chickens. Infect Immun 63, 430-436.

Trampel, D. W., Jensen, N. S. \& Hoffman, L. J. (1994). Cecal spirochetosis in commercial laying hens. Avian Dis 38, 895-898.

Trott, D. J., Stanton, T. B., Jensen, N. S., Duhamel, G. E., Johnson, J. L. \& Hampson, D. J. (1996a). Serpulina pilosicoli sp. nov., the agent of porcine intestinal spirochetosis. Int J Syst Bacteriol 46, 206-215.

Trott, D. J., Atyeo, R. F. Lee, J. I., Swayne, D. E., Stoutenburg, J. W. \& Hampson, D. J. (1996b). Genetic relatedness amongst intestinal spirochaetes isolated from rats and birds. Lett Appl Microbiol 23, 431-436.

van der Zeijst, B. A. M. \& ter Huurne, A. A. H. M. (1997). Molecular biology of intestinal spirochaetes. In Intestinal Spiochaetes in Domestic Animals and Humans, pp. 91-108. Edited by D. J. Hampson \& T. B. Stanton. Wallingford \& New York: CAB International.

Wayne, L. G., Brenner, D. G., Colwell, R. R. \& 9 other authors (1987). International Committee on Systematic Bacteriology. Report of the ad hoc committee on reconciliation of approaches to bacterial systematics. Int J Syst Bacteriol 37, 463-464. 